\title{
Big Five traits as (mal)adaptive behavioural responses to harsh and unpredictable environment: Further evidence for the state- dependent evolution of personality
}

\author{
Janko M. Međedović ${ }^{1}$ \\ Institute of Criminological and Sociological Research
}

\begin{abstract}
State-dependent behaviour models of personality predict that fitness consequences of personality depend on various states. Hence, personality traits may be adaptive only in certain conditions. In the present research, we tested the state-dependent personality model of Big Five personality traits using harsh and unpredictable environments as the extrinsic states. The data were collected on a community sample $(\mathrm{N}=221)$. We extracted the fitness factor from a broader set of indicators related to reproduction and mating. It consisted of higher reproductive success, the longest romantic relationship duration, and earlier age of first reproduction. The only personality trait which significantly predicted fitness was low Openness to experience. However, three interactions between environmental conditions and personality in the prediction of fitness were detected: Low Agreeableness and Extraversion decreased fitness in highly unstable environments; low Openness elevated fitness, especially in harsh environments. The data are in accordance with the previous findings regarding the relations between personality and evolutionary fitness. Furthermore, current findings suggest that state-dependent models of personality are not only valid explanations of evolutionary forces which maintain personality variation, but that they are quite robust as well, since they can be detected in a relatively small sample of reproductively active individuals.
\end{abstract}

Keywords: state-dependent behaviour; Big Five personality traits; environment; fitness; human behavioural ecology

\section{Introduction}

Personality traits as targets for natural selection

Human behavioural ecology (or human evolutionary ecology) is a scientific discipline which explores the evolution of various morphological,

1 janko.medjedovic@fmk.edu.rs 
physiological, and behavioural traits in contemporary humans (Nettle, Gibson, Lawson, \& Sear, 2013). Every trait which is heritable and related to evolutionary fitness (the crucial fitness component is reproductive success - the number of biological offspring) may be under the influence of natural selection. Human personality ecology is a study of evolutionary forces that act on personality traits (Međedović, 2018a). Empirical research in personality ecology was mostly based on the Big Five personality traits (John, Naumann, \& Soto, 2008) - a taxonomy derived via a lexical paradigm which describes five major personality traits: Neuroticism (emotional instability, tendency to experience unpleasant emotions), Extraversion (sociability, gregariousness, heightened activity, positive emotions), Agreeableness (cooperativeness, flexibility, empathy), Conscientiousness (diligence, self-control, responsibility), and Openness to experience (inquisitiveness, aesthetic appreciation, creativity). Research from preindustrial, industrial, and post-industrial populations has shown that personality traits are related to reproductive success as a marker of fitness (Penke \& Jokela, 2016). Extraversion seems to be positively related with reproductive success, especially in males (Bailey, Walker, Blomquist, Hill, Hurtado, \& Geary, 2013; Gurven, von Rueden, Stieglitz, Kaplan, \& Rodriguez, 2014). The opposite seems to hold for Neuroticism - it decreases fitness, again especially in males (Jokela, Alvergne, Pollet, \& Lummaa, 2011), while there are some indications of positive associations in females (Alvergne, Jokela, \& Lummaa, 2010). The findings on other Big Five traits are more heterogeneous. The data mostly point to positive associations between Agreeableness and fitness (Jokela et al., 2011), negative relations between Openness and fitness (Međedović, Šoljaga, Stojković, \& Gojević, 2018), while Conscientiousness was found to have both positive and negative associations with fitness (Alvergne et al., 2010; Dijkstra \&Barelds, 2009). The heterogeneity of data should not surprise us. Evolutionary ecologists assume that behavioural characteristics are adapted to local ecological conditions. Therefore, they are not universally adaptive, but their relations with fitness are context-dependent. This fact alone may produce heterogeneity and complexity regarding the relations between personality and fitness.

\section{State-dependent behaviour models of personality}

The assumption of context-dependent adaptive potentials of personality traits is reflected in another simple fact: the presence of genetic variation in personality (Vukasović \& Bratko, 2015). If personality traits were universally adaptive or maladaptive (i.e. universally increased or decreased fitness), they would be targeted by stabilizing selection. This type of selection erodes genetic variation in a trait: e.g. if Extraversion was universally adaptive, all of us would be Extraverts; conversely, if it was consistently related to lower fitness, all people would be Introverts. Apparently, stabilizing selection 
removes genetic and, consequently, phenotypic variation of a trait. However, personality traits exhibit high levels of individual differences, both on the genetic and phenotypic level. Hence, there may be ultimate factors, i.e. evolutionary forces, which maintain this variation.

State-dependent models of personality are aimed at explaining the variation in personality traits by exploring the conditions which moderate the links between personality and fitness (Sih, Mathot, Moiron, Montiglio, Wolf, \& Dingemanse, 2015). These conditions are labelled as "states" - all circumstances which influence fitness-relevant outcomes of personality (Dingemanse \& Wolf, 2010). States can be extrinsic (environmental conditions) or intrinsic (morphology, physiology, or cognition). Imagine a situation where the same personality trait increased fitness in some, but decreased it in other circumstances; as a result, natural selection could not erode its variation because both phenotypes (the ones both high and low on a trait) could be equally adaptive in different contexts. State-dependent models of personality were relatively successful in explaining personality variation in animals (Sih et al., 2015). However, the research in humans is scarce. There are indications that biological sex is an important stable state which may influence the adaptive potentials of personality traits - the personality characteristics may not be equally adaptive for males and females (Međedović \& Petrović, 2020). There are also indications that the associations between personality and fitness vary across different environments (Gurven et al., 2014). This may be especially true for harsh environments - ecological conditions characterized by scarce resources, elevated deprivation, and stress (Međedović \& Kovačević, 2020). Thus, the existing data suggest that state-dependent behaviour models of personality are plausible conceptual frameworks, which may be used in human personality ecology as well.

\section{Goals of the present research}

Psychologists define personality in different ways, but common aspects of all definitions include the following: 1) existence of individual differences in behaviours, and 2) the fact that these behaviours are relatively stable during ontogeny. However, psychologists rarely ask why there are individual differences in behaviour in the first place. Proximal answers to this question are relatively simple: individual differences emerge from variation in the environments and genetic makeup of individuals. However, the problem becomes more difficult if we ask a question about the ultimate sources of individual differences: why is there variation in gene alleles which participate in personality's phenotypic variation? Here, psychology must turn to evolutionary biology and use concepts from biological disciplines such as behavioural ecology to answer this question. One of the concepts that may help us in providing the answer to a puzzle of variation in personality traits are state-dependent behaviour models. Research on the state-dependent 
behaviour models in humans is still quite rare (but see Međedović, 2018b; Međedović \& Kovačević, 2020), but it is promising regarding the model's potentials to explain one of the fundamental questions of personality.

The primary goal of the present research is to provide another empirical test of the state-dependent models of personality. The current study has two main contributions to previous research on this topic. The first is empirical extraction of the fitness factor. Fitness is usually operationalized as reproductive success - the number of children. We aim to extract the latent factor saturated by the reproductive success and other relevant indicators of mating and reproduction. This is obtained by measuring several parameters which are relevant in modern humans' reproductive ecology. We believe that such fitness factor may represent a more advanced measure of fitness than reproductive success alone.

Previous research that explicitly tested the state-dependent models of personality used environmental harshness as an extrinsic state. However, the research in evolutionary ecology shows that there are at least two environmental characteristics which may represent ecologically important conditions that affect reproduction and behaviour related to fitness: harshness and unpredictability (Belsky, Schlomer, \& Ellis, 2012). These two environmental conditions are positively associated but have some unique relations with the fitness-related outcomes (Brumbach, Figueredo, \& Ellis, 2009). Therefore, we empirically measured both harshness and unpredictability to evaluate their independent effects as external states.

Due to the lack of pervious research, it is difficult to generate the exact hypotheses regarding the environmental moderation of the personalityfitness link. However, it is possible to formulate some assumptions based on previous research on the link between personality and environment. For example, there are data showing lower levels of Extraversion and Openness in ecologies with higher incidence of infective diseases (Schaller \& Murray, 2008). In fact, the authors propose an evolutionary explanation of these findings: Openness and Extraversion are related to spending more time with others, risk taking, and adventure seeking. Hence, these traits may reduce fitness in harsh and dangerous ecologies such as the environments with high incidence of infective diseases. We can even extrapolate this hypothesis to other personality traits as well: harsh and volatile environments may disfavour impulsive and reckless behaviour (low Conscientiousness), selfish and antagonistic behaviour (low Agreeableness) and lack of fear and anxiety (low Neuroticism), because lack of fear could also lead to bold and reckless behaviour. Note that these assumptions are related to environmental harshness - we cannot propose hypotheses regarding unpredictability since there is no research regarding the relations of unpredictability and personality traits, as far as we are aware. Hence, the analysis of unpredictability's role as a moderator of the personality-fitness link is an explorative one. 


\section{Method}

\section{Sample}

The data were collected via an online study. Several students of psychology at the Singidunum University in Belgrade who were interested in the topic of evolution and human behaviour volunteered to disseminate the survey via snowball sampling technique: they administered the survey link to their friends via social networks and asked them to find additional participants. Students did not acquire additional points for disseminating the survey, but the study data were used for their advanced practice in statistics and methodology. Participation in the research was voluntary for all participants. The resulting sample $(\mathrm{N}=221$; all participants were of Serbian nationality) dominantly consisted of female participants (75\%). Most respondents were young adults, although the variation in participants' age was high $(M=24.99$; $\mathrm{SD}=7.03)$. We did not collect the data about the participants' education; we did measure the self-reported socio-economic status. Participants were asked to rate their SES using the seven-point Likert-type scale, where 1 denoted "Much below average" while 7 denoted "Much above average". The majority of our participants had a slightly higher socio-economic status $(\mathrm{M}=4.53 ; \mathrm{SD}=1.09)$.

\section{Measures}

We used the Big Five Inventory (John \& Srivastava, 1999) to measure five lexically-derived personality traits: Neuroticism, Extraversion, Agreeableness, Conscientiousness, and Openness. The inventory has 44 items in total eight items for assessing Neuroticism and Extraversion, nine items for Agreeableness and Conscientiousness, and ten items for Openness.

Environmental harshness was measured via two scales. The first is based on the Weak Socialization scale from the AMORAL inventory (Knežević, 2003). It measures various dysfunctional processes in the family during the participant's childhood, operationalized by five items. It includes indicators of parental maltreatment (e.g., "My parents beat me frequently when I was a child") and neglect ("My parents did not care much about what I did when I was a child"). We also measured childhood poverty (Međedović, 2019) with a simple four-item scale (item examples: "My family never had enough money", "Growing up, there was always a threat that my parents would be out of work"). We combined these two scales into a single measure of Environmental harshness. All previously described scales (personality and environment) are based on self-report methodology with a standard Likert-type scale ranging from 1 to 5: 1 for "I disagree completely" and 5 for "I agree completely".

We measured Environmental unpredictability via a single item. We asked the participants the following: "How unstable was your environment during 
your childhood? Please provide your answers on a five-point scale where 1 stands for "Completely stable" while 5 stands for "Completely unstable". The definitions of stability and instability were added in order to ensure that all participants understood the item in the same way: "Stable" implied that there were no changes or surprising circumstances, while "Unstable" meant that things were constantly changing and there were sudden events.

In order to capture the fitness factor, we measured several indicators of modern humans' reproductive ecology. They were based both on reproduction itself as a crucial fitness component and on some other outcomes which are related to reproduction, including the indicators of mating patterns. Reproductive success was measured via the number of biological children. Desired reproductive success was assessed by the following question: "How many children would you like to have in total?" In order to measure Reproduction planning, we asked the participants the following question: "Is it important for you to plan having children or you think this should happen spontaneously?" The participants who already had children were asked: "Was it important for you to plan having children or did it happen spontaneously?" Participants responded via the following scale: 1) It should be spontaneous/ It was spontaneous; 2) Both planned and spontaneously; 3) It should be planned/It was planned. Age of first reproduction was also measured using two parallel questions, depending on whether the participant already had children: "How old were you when you had your first child?/How old would you like to be when you have your first child?" To measure Contraceptive use we asked the participants how frequently they used various contraceptives and other methods of birth control. The responses were provided on a fivepoint Likert-type scale, where 1 implied "Never" while 5 stood for "Very frequently". Several indicators related to mating were also measured. First of all, we measured the duration of the Longest romantic relationship (in years). We also gathered information of the Age at first sexual intercourse. Finally, we used three indicators to calculate the measure of Short-term mating. They were taken from the Sociosexual Orientation Inventory - Behavior facet (Penke \& Asendorpf, 2008) and included: 1) the number of sexual partners in the preceding 12 months; 2) the number of "one-night stands", and 3 ) the number of partners with whom one had sex despite a lack of the long-term relationship interest. Short-term mating was calculated as the first principal component extracted from these three indicators $(\lambda=2.17 ; 72.21 \%$ of explained variance).

\section{The plan of data analysis}

First, we conducted principal component analysis (PCA) on the measures of mating and reproduction. This was done in order to extract the latent factor of fitness. This factor corresponds to any latent variable loaded by reproductive 
success. Afterwards, we explored the correlations between personality traits, environmental characteristics and fitness. The third analytical step was based on the prediction of fitness by personality and environmental markers. Finally, we calculated the interactions between personality and environment in the prediction of fitness and plotted them graphically.

\section{Results}

\section{Factor analysis of the mating and reproduction measures}

First, we show correlations between the indicators of mating and reproduction and the latent structure of these indicators. Reproductive success was positively associated with the duration of the romantic relationships and desired number of children, and it was negatively related to the Age of first reproduction. The Age at first sexual intercourse was negatively correlated with the duration of romantic relations, use of contraceptives, Reproduction planning, and Short term mating. The individuals who tended to use contraceptives more frequently also tended to delay reproduction, thought that progeny should be planned and desired fewer children in total. They also reported lower age of the first sexual intercourse. Finally, higher desired number of children was positively correlated with Short term mating and negatively with the Age of first reproduction and Reproduction planning. These data are shown in Table 1.

Table 1

Correlations and Principal component analysis of the mating and reproduction measures

\begin{tabular}{|c|c|c|c|c|c|c|c|c|c|c|c|}
\hline & $\mathrm{M}(\mathrm{SD})$ & 1 & 2 & 3 & 4 & 5 & 6 & 7 & Fitness & $\begin{array}{l}\text { Reproduction } \\
\text { planning }\end{array}$ & Mating \\
\hline $\begin{array}{l}\text { 1. Reproductive } \\
\text { success }\end{array}$ & $0.30(0.93)$ & & & & & & & & .87 & & \\
\hline $\begin{array}{l}\text { 2. Longest romantic } \\
\text { relationship }\end{array}$ & $4.03(4.86)$ & $.48^{\star *}$ & & & & & & & .78 & & \\
\hline $\begin{array}{l}\text { 3. Age of first } \\
\text { reproduction }\end{array}$ & $26.86(5.91)$ & $-.35^{\star *}$ & -.05 & & & & & & -.53 & & \\
\hline $\begin{array}{l}\text { 4. Contraceptive } \\
\text { use }\end{array}$ & $2.72(1.53)$ & -.02 & -.02 & $.14^{*}$ & & & & & & .68 & \\
\hline $\begin{array}{l}\text { 5. Age at first sexual } \\
\text { intercourse }\end{array}$ & $18.86(3.56)$ & .09 & $-.14^{*}$ & -.04 & $-.28^{* *}$ & & & & & -.61 & -.51 \\
\hline $\begin{array}{l}\text { 6. Reproduction } \\
\text { planning }\end{array}$ & $2.34(0.74)$ & -.07 & .01 & .02 & $.20^{* *}$ & $-.20^{* *}$ & & & & .61 & \\
\hline $\begin{array}{l}\text { 7. Short-term } \\
\text { mating success }\end{array}$ & $0.01(1.02)$ & -.04 & .02 & .07 & .06 & $-.34^{* *}$ & .05 & & & & .83 \\
\hline $\begin{array}{l}\text { 8. Desired } \\
\text { reproductive } \\
\text { success }\end{array}$ & $2.69(1.47)$ & $.16^{*}$ & -.04 & $-.15^{\star}$ & $-.18^{* *}$ & .00 & $-.16^{*}$ & $.25^{\star *}$ & & -.50 & .67 \\
\hline
\end{tabular}

Notes: ${ }^{\star}-\mathrm{p}<.05 ;{ }^{* *}-\mathrm{p}<.01$; descriptive statistics are shown on the left side; correlations are shown in the middle; the results of PCA are shown in three columns in the right part of the Table (loadings $<.30$ are not shown). 
Latent structure of mating/reproduction indicators corresponds to their bivariate associations. PCA with the Promax rotation resulted in three components with $\lambda>1$. The first extracted component $(\lambda=1.75 ; 21.91 \%$ of explained variance) was positively saturated with the Reproductive success and the Longest romantic relationship, with a negative loading of the Age of first reproduction; this represents a Fitness factor. The second component $(\lambda=1.56 ; 19.44 \%$ of explained variance) was marked by higher Contraceptive use and Reproduction planning, with negative loadings of the Age at first sexual intercourse and the Desired reproductive success. Finally, the third component ( $\lambda=1.33 ; 16.58 \%$ of explained variance) was positively loaded by Short term mating and Desired reproductive success, followed by the negative loading of the Age at first sexual intercourse. These components were not significantly correlated. It should be noted that, in accordance with the main goal of the present research, we only explored the Fitness factor in further analyses.

\section{Correlations between personality, environment, and Fitness}

Next, we show correlations between the main study variables. Our data indicate that environmental harshness and unpredictability are quite congruent ecological conditions. Not only are they only moderately positively related, they also have the same relations with personality traits - negative ones with Conscientiousness, Agreeableness, and Extraversion, and positive with Neuroticism. Fitness was related only to Openness and this relation was negative. These correlations are shown in Table 2.

Table 2

Correlations between personality, environment, and Fitness

\begin{tabular}{|c|c|c|c|c|c|c|c|c|c|}
\hline & $\mathrm{M}(\mathrm{SD})$ & $\alpha$ & 1 & 2 & 3 & 4 & 5 & 6 & 7 \\
\hline 1. Neuroticism & $3.02(0.71)$ & .76 & & & & & & & \\
\hline 2. Extraversion & $3.41(0.70)$ & .78 & $-.29^{\star \star}$ & & & & & & \\
\hline 3. Openness & $3.66(0.66)$ & .81 & -.02 & $.29^{\star *}$ & & & & & \\
\hline 4. Agreeableness & $3.82(0.59)$ & .72 & $-.26^{\star *}$ & $.26^{* *}$ & $.29^{* *}$ & & & & \\
\hline 5. Conscientiousness & $3.36(0.59)$ & .71 & $-.33^{\star *}$ & $.32^{* *}$ & $.19^{* *}$ & $.41^{\star *}$ & & & \\
\hline $\begin{array}{l}\text { 6. Environmental } \\
\text { harshness }\end{array}$ & $2.02(0.72)$ & .82 & $.24^{\star *}$ & $-.25^{\star \star}$ & .11 & $-.29^{\star *}$ & $-.26^{\star *}$ & & \\
\hline $\begin{array}{l}\text { 7. Environmental } \\
\text { unpredictability }\end{array}$ & $2.32(1.09)$ & l & $.35^{\star *}$ & $-.23^{* \star}$ & .07 & $-.24^{\star \star}$ & $-.26^{\star *}$ & $.50^{\star *}$ & \\
\hline 8. Fitness & $0.00(1.00)$ & l & -.07 & .03 & $-.21^{\star *}$ & -.02 & .08 & .01 & -.10 \\
\hline
\end{tabular}


Prediction of fitness: Additive and multiplicative contributions

Our final analysis was aimed at the prediction of fitness. First, we evaluated additive contributions of the predictors and then calculated the interactions between personality traits and the environment. We ran a regression model where fitness was set as the criterion variable, while personality, environment, participants' sex, age, and socio-economic status (measured by asking the participants the following question: "Please rate your socio-economic status on a scale from 1 to 10 , where 1 stands for 'very low' while 10 stands for 'very high.") were set as the predictors. The only significant predictors of fitness were participants' age and low Openness to experience. The contributions of the predictors are shown in Table 3.

Table 3

Prediction of fitness: Basic contributions and interactive effects

\begin{tabular}{|c|c|c|c|c|}
\hline & $\begin{array}{c}\text { Basic } \\
\text { model }\end{array}$ & $\begin{array}{c}\text { First } \\
\text { interaction }\end{array}$ & $\begin{array}{c}\text { Second } \\
\text { interaction }\end{array}$ & $\begin{array}{c}\text { Third } \\
\text { interaction }\end{array}$ \\
\hline $\operatorname{sex}$ & .06 & .07 & .07 & .06 \\
\hline age & $.53^{* *}$ & $.52^{* *}$ & $.53^{* *}$ & $.53^{* *}$ \\
\hline SES & .05 & .05 & .04 & .04 \\
\hline Environmental harshness & .12 & .12 & .09 & $.15^{\star}$ \\
\hline Environmental unpredictability & -.09 & -.09 & -.07 & -.07 \\
\hline Neuroticism & -.03 & -.03 & -.07 & .00 \\
\hline Extraversion & .12 & .12 & .11 & .11 \\
\hline Openness & $-.22^{\star *}$ & $-.21^{\star *}$ & $-.22^{\star *}$ & $-.22^{\star *}$ \\
\hline Agreeableness & .06 & .04 & .05 & .07 \\
\hline Conscientiousness & .01 & .02 & .01 & .03 \\
\hline $\mathrm{F}$ & $12.00^{\star *}$ & & & \\
\hline $\mathrm{R}^{2}$ & .34 & & & \\
\hline $\mathrm{A}^{\star}$ Environmental unpredictability & & .12 & & \\
\hline$\Delta \mathrm{F}$ & & $4.19^{*}$ & & \\
\hline$\Delta \mathrm{R}^{2}$ & & .01 & & \\
\hline $\mathrm{E}^{\star}$ Environmental unpredictability & & & .15 & \\
\hline$\Delta \mathrm{F}$ & & & $6.19^{*}$ & \\
\hline$\Delta \mathrm{R}^{2}$ & & & .02 & \\
\hline $\mathrm{O}^{\star E n v i r o n m e n t a l ~ h a r s h n e s s ~}$ & & & & -.13 \\
\hline$\Delta \mathrm{F}$ & & & & $4.50^{*}$ \\
\hline$\Delta \mathrm{R}^{2}$ & & & & .01 \\
\hline
\end{tabular}

Notes: ${ }^{*}-\mathrm{p}<.05 ;{ }^{* *}-\mathrm{p}<.01 ;$ Standardized regression coefficients are shown as the statistics of the predictors' contribution to the regression function

Secondly, we calculated the interactions between the personality traits, environmental harshness, and unpredictability. Hence, ten interactions were tested in total. We did not apply any corrections to multiple testing for 
two reasons: 1) the number of conducted analyses was not too high, and, for that reason we do not believe that the probability of type 1 error was highly elevated; 2 ) significant interactions obtained on the samples with a relatively small size usually have more liberal $\mathrm{p}$-values $(\mathrm{p}<.05)$; therefore, if we had applied corrections for p-values, we would have diminished our chances to detect any significant interactions in the first place. Interactions were calculated as the products of the centred predictors' measures. Three of them proved to be statistically significant and they are shown in Table 3 as well. Their graphical representations revealed that lower Agreeableness and Extraversion are related to lower Fitness in more unpredictable environments; lower Openness is associated with increased Fitness in harsher environments. Graphical representations of interactions are shown in Figures 1,2 , and 3 (since the criterion variable is a standardized measure, intercept is arbitrarily fixed at value 3 ).

Diagram 1

Interaction between Agreeableness and Environmental unpredictability in the prediction of Fitness

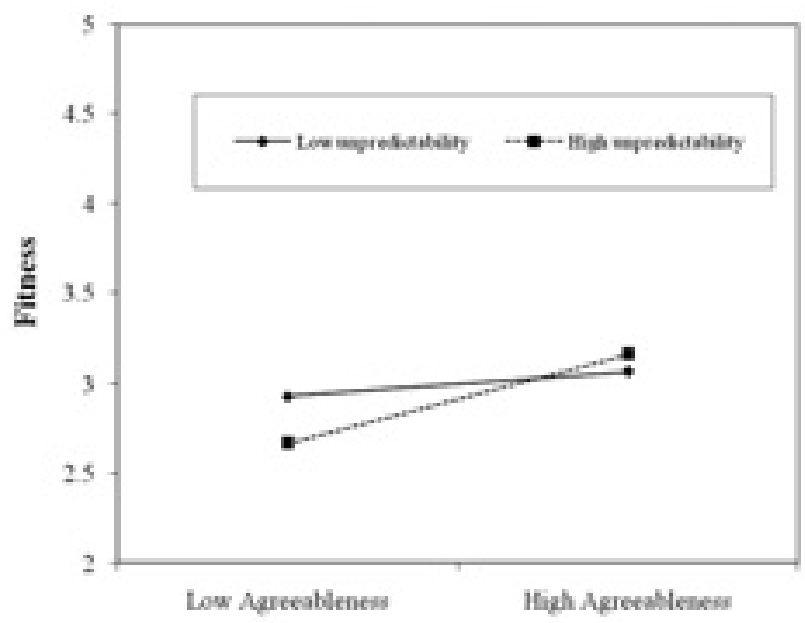


MEĐEDOVIĆ J. M.: BIG FIVE TRAITS AS (MAL)ADAPTIVE BEHAVIOURAL RESPONSES

\section{Diagram 2}

Interaction between Extraversion and Environmental unpredictability in the prediction of Fitness

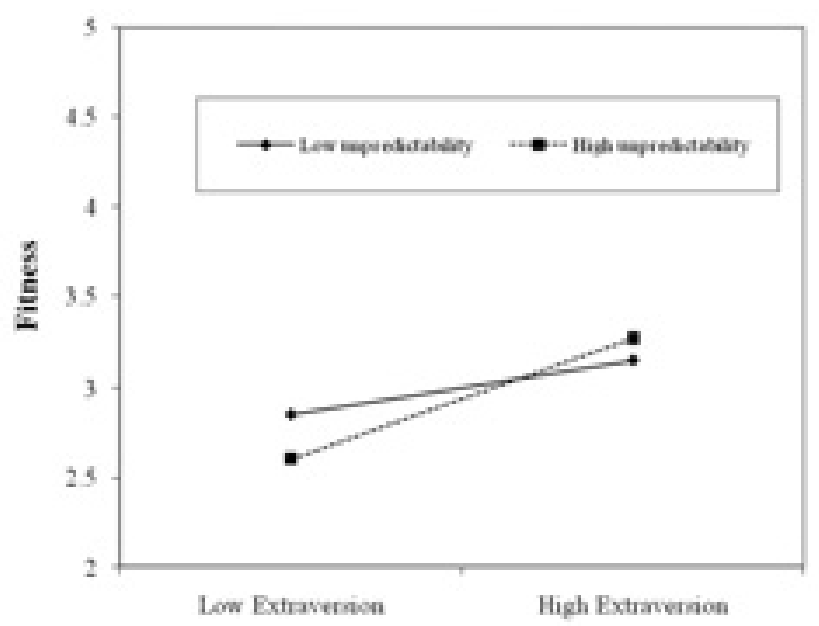

Diagram 3

Interaction between Openness and Environmental harshness in the prediction of Fitness

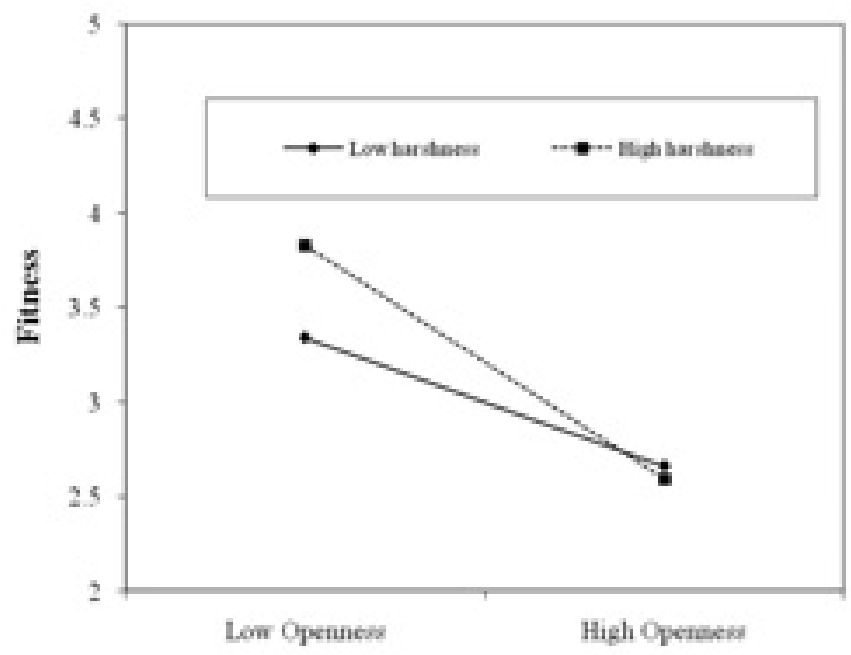




\section{Discussion}

Personality is defined as the existence of individual differences in behavioural patterns. However, psychologists rarely examine if there are ultimate (evolutionary) forces which maintain this inter-individual variation. Hence, this is one of fundamental problems of personality: Why do individuals differ in stable behavioural patterns, or, in other words, why have not individual differences been removed by stabilizing selection? This is one of the key questions in the behavioural ecology of personality, a scientific discipline which examines evolutionary forces acting on personality, especially in the context of local ecologies (Dingemanse \& Wolf, 2010; Međedović, 2018a). In the present research, we used a state-dependent behaviour model (Sih et al., 2015) to examine the relations between personality traits, environmental characteristics and fitness. In accordance with the model, we found interactions between personality and the environment in the prediction of fitness. This finding implies that personality traits are not universally adaptive, but that their adaptive (and maladaptive) potentials are context dependent. In this case, they are contingent on the environmental characteristics of harshness and unpredictability. Therefore, natural selection cannot deplete the variation in personality, because its relations with fitness vary across contexts. Consequently, this implies that various personality phenotypes may be adaptive in different ecologies.

\section{Relations between the mating and reproduction indicators - the fitness factor extraction}

The correlations between the indicators of mating and reproduction reveal crucial characteristics of modern humans' reproductive ecology. Most importantly, we should consider the fitness factor, empirically extracted from these indicators' covariation. Reproductive success is highly dependent on the timing of the first reproduction - the individuals who start reproducing earlier in their lifetime also have more offspring. This is a highly stable and replicable finding, both on the phenotypic and genetic level (Sanjak, Sidorenko, Robinson, Thornton, \& Visscher, 2018; Sheppard, Pearce, \& Sear, 2016; Tropf, Stulp, Barban, Visscher, Yang, Snieder, \& Mills, 2015). More interestingly, reproductive success is contingent on the duration of partner relations. The individuals who have longer romantic relationships tend to have more children. This result was obtained in previous studies as well (Međedović, 2019). The established link probably has both proximate causes (the more time you spend with your romantic partner, the more frequently you think about starting a family with her/him) and ultimate determinants. Stable relationships elevate the probability that partners will raise their 
children together as well, which produces biparental care, important for human babies and children (Stewart-Williams\& Thomas, 2013). Finally, reproductive success correlated positively with the desired number of children, although the latter was not loaded on the Fitness factor. This result reflects one of the major characteristics of reproduction in contemporary humans: due to contraceptives and other birth control technologies, humans are able to control their reproduction to a certain extent (Johnson-Hanks, 2008). This is why motivation for childbirth and raising children correlates with the observed fertility (Miller, Rodgers, \& Pasta, 2010). Hence, it is fruitful to search for a fitness factor in the indicators of mating and reproduction. This factor certainly represents a better measure of fitness compared to a single indicator of reproductive success. The crucial question is the replicability of this factor across samples, but this is an empirical question and future research may provide an answer to it.

\section{Openness to experience decreases fitness}

The only personality trait which was independently related to fitness was low Openness to experience. Certainly, we expected more significant associations, but their absence is probably a consequence of the low sample size. However, negative associations between Openness and reproductive success were detected in a large number of previous studies. These studies have found negative links both with the number of children (Berg, Rotkirch, Väisänen, \& Jokela, 2013; Jokela et al., 2011; Međedović et al., 2018; Međedović \& Kovačević, 2020; Skirbekk \& Blekesaune, 2014) and grandchildren (Berg, Lummaa, Lahdenperä, Rotkirch, \& Jokela, 2014). It seems that Openness decreases fitness, but we may wonder why this is the case. Openness positively correlates with intelligence, which seems to negatively predict fitness as well (Meisenberg, 2010; Reeve, Lyerly, \& Peach, 2013). More open individuals usually strive for higher educational achievements, which are negatively related to fitness as well, even on a genetic level (Beauchamp, 2016). The latter connection is probably the reason why the negative link between Openness and reproductive success is more characteristic of newer cohorts compared to the older ones (Jokela, 2012). However, this poses an important question regarding the mean levels of Openness and its variation in future human populations. Are there some fitness components which may be positively affected by Openness, such as longevity or parental investment? Or Openness may be reliably related to lower fitness, but this link is a new one in an evolutionary sense and that is the reason why there are no phenotypic population changes yet. If latter is the case, and this link remains stable across generations, then phenotypic levels of Openness may tend to drop in future human populations, together with its inter-individual variation. 


\section{Environment moderates the links between personality and fitness}

The crucial assumption of the state-dependent behaviour models is that state influences the relations between personality traits and fitness. Environmental characteristics are often measured as extrinsic states that may cause variation in the links between personality and fitness. It is argued that harshness and unpredictability represent some of the crucial ecological conditions which affect fitness-related outcomes (Belsky et al., 2012; Brumbach et al., 2009). In the present research, we did not observe direct links between environmental conditions and fitness, but detected moderation effects of the environment on the personality-fitness link, which is in line with previous studies (Međedović, 2018b; Međedović \& Kovačević, 2020). Low Agreeableness and Extraversion decrease fitness in the conditions of high environmental instability/unpredictability. These results complement and specify previous findings of positive relations between these two personality traits and fitness (Bailey et al., 2013; Gurven et al., 2014; Jokela et al., 2011). Openness is generally negatively related to fitness, but this negative effect is more pronounced in harsher environments in the present data. Interestingly, one previous study also found that the links between Openness and reproductive success in males depended on geographical conditions (Gurven et al., 2014). This study was conducted in a small-scale subsistence society, where there was no massive education and reproductive control. Hence, this finding is congruent with the hypothesis that a negative link between Openness and fitness is of recent evolutionary origin.

It is thought-provoking to compare the associations between environment and personality with the environmentally-dependent links between personality and fitness. For example, environmental unpredictability negatively correlates with Extraversion and Agreeableness; however, in those same conditions, these personality traits negatively predict fitness! Therefore, low Agreeableness and Extraversion can be maladaptive responses to unpredictable environment. Apparently, unpredictable environment may support the evolution of more prosocial behavioural strategies because this is the common core of Agreeableness and Extraversion personality traits. Openness did not correlate with environmental characteristics in the present data. However, previous research has shown that Openness is lower in harsh environmental conditions (Međedović, 2018b; Međedović \& Kovačević, 2020). If this is the case, then lower Openness may be an adaptive behavioural response to harsh environment, because it is exactly the type of environment where Openness elevates fitness. This hypothesis sounds intriguing, but before we hypothesize about the possible processes which cause adaptive and maladaptive behavioural responses, the described results must be replicated in future empirical studies. 


\section{Limitations and future directions}

There are several important limitations of the present research. Most of them are related to the sample size and structure. The number of participants in the present study was relatively small, most of them were younger adults and the majority of participants were female. The sample size is an important parameter in the research regarding reproductive events since the effect sizes are small and higher sample sizes are required to capture them; alternatively, the probability of Type 2 error is higher. Sample structure is relevant as well: the best measure of reproductive success is the lifetime number of children and it can be obtained from post-reproductive individuals (aged above 50 or 55). Finally, environmental characteristics could be measured objectively, which may be an advantage because objective measures are not sensitive to recollection and other memory biases. If objective data cannot be collected, multi-item self-report scales of environmental conditions would provide more reliable data than the single-item measures, which we administered in the present study. In addition to these limitations, future research could explore other states, especially the intrinsic ones, such as body mass, height or cognitive abilities.

\section{Concluding remarks}

Human personality ecology is an exciting and intriguing scientific discipline which can help us provide answers to fundamental questions related to personality. One of these questions is the existence of individual differences in behaviour, in the first place. The discipline is still in its infancy, empirical findings are rare, but they are promising: many empirical studies have confirmed that personality is indeed related to fitness. Now, we should make further steps and ask more complex questions regarding the forces of natural selection which operate on personality traits. These questions can reveal adaptive potentials of personality and, more importantly, the interplay of personality and ecological contexts of individuals which generate evolutionary dynamics regarding personality traits. The data presented in the manuscript are encouraging in this sense, because they show that the effects in question can be found even in relatively small samples, which suggests their robustness. This may be a further incentive for researchers to explore personality in an evolutionary context and help in advancing human personality ecology as a research field.

\section{References:}

Alvergne, A., Jokela, M., \& Lummaa, V. (2010). Personality and reproductive success in a high-fertility human population. Proceedings of the National Academy of Sciences, 107, 11745-11750. http://dx.doi.org/10.1073/pnas.1001752107 
Bailey, D. H., Walker, R. S., Blomquist, G. E., Hill, K. R., Hurtado, A. M., \& Geary, D. C. (2013). Heritability and fitness correlates of personality in the Ache, a natural-fertility population in Paraguay. PLoS One, 8, e59325. http://dx.doi. org/10.1371/ journal.pone.0059325

Beauchamp, J. P. (2016). Genetic evidence for natural selection in humans in the contemporary United States. Proceedings of the National Academy of Sciences, 113(28), 7774-7779. https://doi.org/10.1073/pnas.1600398113

Belsky, J., Schlomer, G. L., \& Ellis, B. J. (2012). Beyond cumulative risk: distinguishing harshness and unpredictability as determinants of parenting and early life history strategy. Developmental psychology, 48(3), 662-673. https://psycnet.apa. org/doi/10.1037/a0024454

Berg, V., Lummaa, V., Lahdenperä, M., Rotkirch, A., \& Jokela, M. (2014). Personality and long-term reproductive success measured by the number of grandchildren. Evolution and Human Behavior, 35(6), 533-539. https://doi.org/10.1016/j. evolhumbehav.2014.07.006

Berg, V., Rotkirch, A., Väisänen, H., \& Jokela, M. (2013). Personality is differentially associated with planned and non-planned pregnancies. Journal of Research in Personality, 47(4), 296-305. https://doi.org/10.1016/j.jrp.2013.01.010

Brumbach, B. H., Figueredo, A. J., \& Ellis, B. J. (2009). Effects of harsh and unpredictable environments in adolescence on development of life history strategies. $\mathrm{Hu}$ man Nature, 20(1), 25-51. https://doi.org/10.1007/s12110-009-9059-3

Dijkstra, P., \&Barelds, D. P. H. (2009). Women's well-being: The role of individual differences. Scandinavian Journal of Psychology, 50, 309-315. http://dx.doi. org/10. 1111/j.1467-9450.2009.00711.x

Dingemanse, N. J., \& Wolf, M. (2010). Recent models for adaptive personality differences: a review. Philosophical Transactions of the Royal Society of London B: Biological Sciences, 365, 3947-3958. doi:10.1098/rstb.2010.0221

Gurven, M., von Rueden, C., Stieglitz, J., Kaplan, H., \& Rodriguez, D. E. (2014). The evolutionary fitness of personality traits in a small-scale subsistence society. Evolution and Human Behavior, 35, 17-25. http://dx.doi.org/10.1016/j.evolhumbehav.2013. 09.002

John, O.P., Naumann, L.P., \& Soto, C.J. (2008). Paradigm shift to the integrative Big Five trait taxonomy: History, measurement, and conceptual issues. In O.P. John, R.W. Robins, \& L.A. Pervin (Eds.), Handbook of personality: Theory and research (pp. 114-158). New York: Guilford.

John, O. P., \& Srivastava, S. (1999). The big five trait taxonomy: History, measurement, and theoretical perspectives. In L. A. Pervin, \& O. P. John (Eds.), Handbook of personality: Theory and research (pp. 102-138). New York: Guilford Press.

Jokela, M. (2012). Birth-cohort effects in the association between personality and fertility. Psychological Science, 23, 835-841. https://doi.org/10.1177\%2F0956797612439067

Jokela, M., Alvergne, A., Pollet, T. V., \&Lummaa, V. (2011). Reproductive behavior and personality traits of the Five Factor Model. European Journal of Personality, 25, 487-500. http://dx.doi.org/10.1002/per.822

Johnson-Hanks, J. (2008). Demographic transitions and modernity. Annual review of anthropology, 37, 301-315. https://doi.org/10.1146/annurev.anthro.37.081407.085138

Knežević, G. (2003). Koreni amoralnosti [The roots of amorality]. Beograd: Institut za kriminološka i sociološka istraživanja, Institut za psihologiju. 
Međedović, J. (2018a). What can human personality psychology learn from behavioral ecology? Journal of Comparative Psychology, 132(4), 382-394. https://doi. org/10.1037/com0000120

Međedović, J. (2018b). Testing the state-dependent behavior models in humans: Environmental harshness moderates the link between personality and mating. Personality and Individual Differences, 125, 68-73. https://doi.org/10.1016/j. paid.2017.12.035

Međedović, J. (2019). Examining the link between religiousness and fitness in a behavioural ecological framework. Journal of Biosocial Science, advance online publication. https://doi.org/10.1017/S0021932019000774

Međedović, J., \& Kovačević, U. (2020). Personality as a state-dependent behavior: Do childhood poverty and pregnancy planning moderate the link between personality and fitness? Personality and Individual Differences, 154, 109625. https://doi. org/10.1016/j.paid.2019.109625

Međedović, J. \& Petrović, B. (2020). Relationships between basic emotions and reproductive fitness are moderated by sex as an internal state. Primenjena Psihologija, 13, 5-26. https://doi.org/10.19090/pp.2020.1.5-26

Međedović, J., Šoljaga, M., Stojković, A., \& Gojević, I. (2018). Revealing complex relations between personality and fitness: HEXACO personality traits, life-time reproductive success and the age at first birth. Personality and Individual Differences, 129, 143-148. https://doi.org/10.1016/j.paid.2018.03.014

Meisenberg, G. (2010). The reproduction of intelligence. Intelligence, 38(2), 220-230. https://doi.org/10.1016/j.intell.2010.01.003

Miller, W. B., Rodgers, J. L., \& Pasta, D. J. (2010). Fertility motivations of youth predict later fertility outcomes: A prospective analysis of national longitudinal survey of youth data. Biodemography and social biology, 56(1), 1-23. https://doi. org/10.1080/ 19485561003709131

Nettle, D., Gibson, M. A., Lawson, D. W., \& Sear, R. (2013). Human behavioral ecology: current research and future prospects. Behavioral Ecology, 24(5), 10311040. https://doi.org/10.1093/beheco/ars222

Penke, L., \&Asendorpf, J. B. (2008). Beyond global sociosexual orientations: a more differentiated look at sociosexuality and its effects on courtship and romantic relationships. Journal of personality and social psychology, 95(5), 1113-1135. https://psycnet.apa.org/doi/10.1037/0022-3514.95.5.1113

Penke, L., \& Jokela, M. (2016). The evolutionary genetics of personality revisited. Current Opinion in Psychology, 7, 104-109. https://doi.org/10.1016/j.copsyc.2015.08.021

Reeve, C. L., Lyerly, J. E., \& Peach, H. (2013). Adolescent intelligence and socio-economic wealth independently predict adult marital and reproductive behavior. Intelligence, 41(5), 358-365. https://doi.org/10.1016/j.intell.2013.05.010

Sanjak, J. S., Sidorenko, J., Robinson, M. R., Thornton, K. R., \& Visscher, P. M. (2018). Evidence of directional and stabilizing selection in contemporary humans. Proceedings of the National Academy of Sciences, 115(1), 151-156. https:// doi.org/10.1073/pnas.1707227114 
Schaller, M., \& Murray, D. R. (2008). Pathogens, personality, and culture: Disease prevalence predicts worldwide variability in sociosexuality, extraversion, and openness to experience. Journal of Personality and Social Psychology, 95(1), 212221. https://psycnet.apa.org/doi/10.1037/0022-3514.95.1.212

Sheppard, P., Pearce, M. S., \& Sear, R. (2016). How does childhood socioeconomic hardship affect reproductive strategy? Pathways of development. American Journal of Human Biology, 28(3), 356-363. https://doi.org/10.1002/ajhb.22793

Sih, A., Mathot, K. J., Moiron, M., Montiglio, P. O., Wolf, M., \& Dingemanse, N. J. (2015). Animal personality and state-behaviour feedbacks: a review and guide for empiricists. Trends in Ecology \& Evolution, 30(1), 50-60.

Skirbekk, V., \& Blekesaune, M. (2014). Personality traits increasingly important for male fertility: Evidence from Norway. European Journal of Personality, 28(6), 521-529. https://doi.org/10.1002/per.1936

Stewart-Williams, S., \& Thomas, A. G. (2013). The ape that thought it was a peacock: Does evolutionary psychology exaggerate human sex differences? Psychological Inquiry, 24(3), 137-168. https://doi.org/10.1080/1047840X.2013.804899

Tropf, F. C., Stulp, G., Barban, N., Visscher, P. M., Yang, J., Snieder, H., \& Mills, M. C. (2015). Human fertility, molecular genetics, and natural selection in modern societies. PLoS One, 10, e0126821. https://doi.org/10.1371/journal.pone.0126821

Vukasović, T., \& Bratko, D. (2015). Heritability of personality: a meta-analysis of behavior genetic studies. Psychological Bulletin, 141(4), 769-785. https://psycnet. apa.org/ doi/10.1037/bul0000017

\title{
Crte Velikih Pet kao (mal)adaptivni bihejvioralni odgovori na oštro i nepredvidivo okruženje: novi dokazi za evoluciju ličnosti zavisnu od stanja
}

\author{
Janko M. Međedović \\ Institut za kriminološka i sociološka istraživanja
}

Modeli ličnosti zavisni od stanja predviđaju da će efekti ličnosti na adaptivnu vred-
nost zavisiti od različitih stanja; dakle, crte ličnosti mogu biti adaptivne samo u
određenim uslovima. U ovom istraživanju testirali smo model ličnosti zavistan od
stanja primenjen na crte Velikih Pet koristeći oštrinu i nepredvidivost okruženja
kao ekstrinzička stanja. Podaci su prikupljeni na prigodnom uzorku selektovanom
iz zajednice $(\mathrm{N}=221)$. Prvo smo ekstrahovali faktor adaptivne vrednosti iz šireg
seta indikatora povezanih sa reprodukcijom i sparivanjem - on se sastojao od
većeg reproduktivnog uspeha, dužeg trajanja romantičnih partnerskih veza i ra-
nijeg uzrasta prve reprodukcije. Jedina crta ličnosti koja je značajno predviđala
adaptivnu vrednost bila je niska Otvorenost za iskustva. Međutim, tri interakcije
između sredinskih uslova i ličnosti su pronađene pri predikciji adaptivne vrednos-
ti: niska Saradljivost i Ekstravezija su asocirane sa nižom adaptivnom vrednošću u 
veoma nestabilnim okruženjima; niska Otvorenost je pozitivno povezana sa adaptivnom vrednošću pogotovo u oštrim okruženjima. Podaci su u skladu sa prethodnim nalazima o odnosima između ličnosti i evolucione adaptivne vrednosti. Dobijeni rezultati sugerišu da su modeli ponašanja zavisni od stanja ne samo validni za objašnjenje evolucionih procesa koji održavaju varijansu u crtama ličnosti već da su i prilično robusni jer se efekti mogu detektovati u relativno malim uzorcima reproduktivno aktivnih individua.

Ključne reči: ponašanje zavisno od stanja; Velikih Pet; sredina; adaptivna vrednost; ljudska bihejvioralna ekologija 